\title{
Çevresel Maliyet Yönetiminin Ürün Yaşam Seyri Maliyetleme Açısından İncelenmesi
}

\author{
Mustafa ARI \& Gökhan BAYRAM²
}

$\ddot{\mathbf{O z}}$

Günümüzde teknolojinin hızla gelişmesine bağlı olarak ürün yaşam seyri kısalmakta ve maliyet yönetiminin önemi artmaktadır. Bunun yanında çevrenin korunması ile ilgili duyarlılıkların ve çevre bilincinin her geçen gün artması mal ve hizmetlerin tasarım aşamasından tüketim aşamasına çevresel etkilerinde hesaba katılması gerekmektedir. Artan rekabet koşulları, sürekli mal ve hizmetlerde iyileştirme ve geliştirme zorunluluğu, toplumun aşırı tüketime yönlendirme gibi olaylar beraberinde çevre sorunlarını da getirmiştir. Çevresel sorunların her geçen gün önem kazanmasıyla, işletmelerin çevreye karşı daha sorumlu bir tutum ve çevresel maliyetlerin yönetilmesini dikkate almaları bir zorunluluk haline getirmiştir. Bu durum çevresel maliyet yönetim sorunlarını ortaya çıkarmıştır.

Ürün yaşam seyri maliyet yöntemi, bir ürünün tüm yaşam seyri boyunca ortaya çıkması muhtemel olan maliyetlerin yönetimini amaçlamaktadır. Ürün yasam seyri maliyet yönetiminin bu bakış açısı, bir ürünün tüm yaşam seyri boyunca neden olacağı maliyetler toplamının, ürünün tüm yaşam seyri boyunca işletmeye sağladığı gelirler toplamı ile karşılaştırılarak ürünün gerçek karlılık durumunun ortaya çıkmasını sağlamaktadır. Ürün yaşam seyri maliyet yöntemi, çok geniş uygulama alanına sahip bir yöntemdir. Özellikle, günümüzün ve yarının en önemli konularından olan çevre maliyetlerinin ürün yaşam seyri maliyet yönteminin analizlerine dahil edilerek değerlendirilmesi, maliyet yönetim sorunlarının çözümüne yardımcı olacağı düşünülmektedir.

Anahtar Kelimeler: Çevresel Maliyet Yönetimi, Çevresel Maliyetler, Ürün Yaşam Seyri, Ürün Yaşam Seyri Maliyetleme

\section{Investigation of Environmental Cost Management in terms of Product Life Cycle Costing}

\begin{abstract}
Nowadays, due to the rapid development of technology, the life cycle of the product is shortened and the importance of cost management is increasing. In addition to this, it is necessary to take into consideration the environmental awareness of the environment and the environmental impacts of the goods and services from the design stage to the consumption phase. Increasing competition conditions, the necessity of continuous improvement of the goods and services and the events such as directing society to excessive consumption have brought environmental problems. With environmental problems becoming more and more important, it has become a necessity for enterprises to consider a more responsible attitude towards the environment and management of environmental costs. This has led to environmental cost management problems.

The product life cycle cost method aims to manage the costs that are likely to occur during the entire life cycle of a product. This perspective of product life cycle cost management ensures the real profitability of the product by comparing the sum of the costs that a product will cause throughout its entire life cycle with the sum of the revenues it provides to the enterprise throughout its life cycle. Product life cycle cost method is a method with wide application area. In particular, it is considered that the evaluation of environmental costs, which are one of the most important issues of today and tomorrow, by including them in the analysis of the product life cycle cost method will help to solve the cost management problems.
\end{abstract}

Keywords: Environmental Cost Management, Environmental Costs, Product Life Cycle, Product Life Cycle Costing

\footnotetext{
1 Dr. Öğr. Üyesi, Bilecik Şeyh Edebali Üniversitesi, İdari ve İktisadi Bilimler Fakültesi, İşletme Bölümü, mustafa.ari@bilecik.edu.tr

$\frac{2}{2}$ Doktora Öğrencisi, Kocaeli Üniversitesi, Sosyal Bilimler Enstitüsü, Muhasebe Finansman Bölümü, gokhanbayram1165@gmail.com
} 


\section{GíRiș}

İşletmeler faaliyetleri gereği çevreyle etkileşim içindedirler. Bu etkileşim sonucu işletmeler faaliyetlerini gerçekleştirirken doğal kaynakları kullanmak durumunda olacaklardır. Sınırlı kaynakların bilinçsiz tüketilmesi ve bireylerin toplumsal sorunlar konusunda bilinçlenmesine yol açmıştır. $\mathrm{Bu}$ bilinçlenme sonucunda işletmelerin, ürünlerin tasarım noktasından tüketim noktasına kadar yani ürünlerin üretilme kararı verilip ortaya çıkması ve üretimine son verilmesi aşamalarını kapsayan bu geniş süreci anlatan ürün yaşam seyri, bu noktada işletme ve tüketici arasındaki güçlü bağın önemini ortaya çıkarmıştır. Teknolojinin gelişmesi ve artan rekabet sonucu işletmeler sadece mal ve hizmet üretmeleri yeterli gelmemektedir. Mal ve hizmetlerin tasarım noktasından tüketim noktasına kadar olan tüm süreçlerde ürünün çevreye karşı duyarlılığını dikkate alan bir işletme anlayışı yer almıştır. Çünkü çevrenin korunması ile ilgili duyarlı1ıkların ve çevre bilincinin her geçen gün artması toplumla birlikte işletmelerin de faaliyetlerini yerine getirirken daha sorumlu bir tutum izlemeye yöneltmektedir.

Çevreye duyarlı yönetim anlayışının ortaya çıkış noktası sürdürülebilir kalkınma anlayışından gelmektedir (Karabulut, 2004: 53). Son yıllarda sürdürülebilir kalkınma anlayışı ve çevre koruma bilincinin artmasıyla birlikte, işletmelerin çevreye bakış açılarında önemli bir değişim yaşanmıştır (Nemli, 2000: 113). İşletme yöneticileri de değişimin gerisinde kalmamak için bu yöndeki talepleri stratejik kararlarda dikkate almalıdır. Çevreye karşı daha duyarlı bir yönetim anlayışı geliştirmek durumundadırlar (Başaran, 2009: 9). Çevreye karşı duyarlı yönetim anlayışı çevresel maliyetleri ortaya çıkarmaktadır. Çevresel maliyetlerin gün geçtikçe artması ile birlikte çevresel maliyet yönetiminin önemini daha da arttırmıştır.

Birçok ülkede işletmeler rekabet avantaj1 elde etmek için çevresel maliyetlere katlanmak istememektedir. Bu işletmelerin çevreye vermiş oldukları kirlilik nedeniyle küresel 1sınma oluşmakta bunun sonucunda tüm dünya canlıları büyük bir tehlike ile karşı karşıya kalmaktadır. Ani ve şiddetli iklim değişiklikleri insanları ve diğer canlılara büyük zararlar vermekte ve çok büyük maddi hasarlara neden olmaktadır. Bu açıdan çevresel maliyet yönetimi uluslararası düzeyde ele alınıp yönetilmesi gerekliliği ortaya çıkmıştır. Çevresel maliyet aynı zamanda tüm ürün yaşam seyri boyunca ele alınıp bir bütün olarak yönetilmelidir.

Çevresel maliyetlere katlanmak istemeyen ülkeler ve şirketler tüm dünyamızı risk altına atmaktadır. Günümüzde ortaya çıkan doğal afetler, ani iklim değişikliklerin küresel 1sınma gibi sorunların kaynağı çevreye karşı duyarlı olmayan çevresel maliyetlere katlanmak istemeyen işletmelerin olduğu bilimsel çalışmalarla ortaya konmaktadır. Ortaya çıkan bu çevresel sorunların çözümü için tüm dünya ülkelerindeki işletmeleri kapsayacak şekilde, ürün yaşam seyri boyunca çevresel maliyetlerin belirlenmesi ve yönetilmesi gerekliliği ortaya çıkmıştır. Bu çalışmamızda çevresel maliyetlerin yönetimi ürün yaşam seyri kapsamında teorik bir yaklaşım ile incelenmeye çalışılmıştır. 


\section{1. ÇEVRESEL MALIYET YÖNETIMI}

Maliyet, belirli bir amaca ulaşabilmek için katlanılan fedakarlıkların parasal ifadesidir (Karakaya, 2006: 14). "Çevresel maliyetler ise, işletmelerin hedef kitlelerine mal veya hizmet sunmak için katlandıkları maliyetlerden biri olarak kabul edilmektedir“ (Özbirecikli, 2000: 18). Maliyetlerin muhasebe sistemlerine göre ayrı ayrı sınıflandırılması ve çevre bilincinin gelişmesine bağlı olarak harcamaların artması sonucu çevre maliyeti kavramı ortaya çıkmıştır (Coşkun ve Karaca, 2008: 60). Yani işletmelerin mamül üretimi veya mamül hizmeti boyunca çevreye karşı duyarlı davranmak için katlandıkları fedakarlıkların toplam değeridir.

Maliyet yönetimi kavramı, "işletmenin ürünlerinin ve işlemlerinin geliştirilmesi amaciyla planlama yapmak, ölçümlemek ve geri bildirim sağlamak için kullanılan bir grup teknik ve yöntem” (Gündüz, 1997: 33) olarak tanımlanmaktadır. Maliyet yönetimi, ürün maliyetlerini doğru belirlemek, işletmedeki işlemleri geliştirmek, israfı önlemek, maliyet taşıyıcılarını tanımlamak, faaliyetleri planlamak ve işletmenin stratejilerini oluşturmak için faaliyetlerin yönetimi ve kontrolüdür. İşletmelerde ürün hatlarının gelişmesine kullanılan teknolojilerin değişmesine, ürünlerin hayat seyrinin kısalmasına, küresel rekabet koşullarının farklılaşmasına ve bilgi teknolojilerindeki büyük değişikliklere cevap vermek amacıyla, yöneticilerin daha etkin ve zamanında bilgi sunabilen bir maliyet sistemi geliştirmeleri zorunlu olmuştur. $\mathrm{Bu}$ önemli değişmeler karşısında maliyet muhasebesi, maliyet yönetimi için ilgili ve etkin olmaktan çıkarak ilgisini yeni yöntemlere bırakmıştır (Titiz ve Çetin, 2000: 125).

Çevresel maliyetlere çevresel kalite maliyetleri de denilebilir. Çevresel maliyetler çevresel kalitenin zayıf olduğu veya çevresel kalitenin zayıf olabileceği durumlarda meydana gelen maliyetlerdir (Hansen ve Mowen, 2000: 668). Sosyal nedenler, müşteri gereklilikleri ve yasal düzenlemeler gibi unsurlar işletmelerin çevresel maliyetlere önem vermesinde etkili olan faktörlerdir (Esmeray ve Tanç, 2009: 243).

Çevre maliyetlerinin çok sayıda amaçları vardır. Bu amaçlar (Abdüsseyyid, Sultan, ve Yusuf, 2007: 9):

$>$ Daha fazla çevre standartlarına sahip ürünleri bildirmek ve piyasaya sürmekle şirket ürünlerinin rekabetini gerçekleştirmek.

> İşletme çalışmalarının çevre üzerindeki olumsuz etkilerinin araştırılması, bununla bağlantılı olarak koruma programının konulması ve bu program için bütçenin belirlenmesi. Ayrıca bunun şirket kârı üzerindeki etkisinin araştırılması.

$>$ Örgütlerin yıllık raporlarına çevre maliyetlerinin sokulması, devletin farklı bölgelerinin çevre kirliliği unsurlarının denetlenmesi konusunda devletin ilgili birimlerine yardımcı olur. 
$>$ Nicel ve finansal tüm bilgileri sağlayarak çevre yönetim sistemini desteklemek. Bu da çevre maliyetlerinin en az olduğu alternatifi seçmek için sunulan alternatifler arasında tercih ve karşılaştırma yapmaya yardımcı olur.

Çevreyi korumaya bağlılık sebebiyle vergi affı veya indirimlerinin olabilmesi ve banka kredilerinin alınabilme imkanı.

> Kararları doğru almada yönetime yardımcı olmak. Dolayısıyla kuruluşların itibar ve değeri olur.

$>$ Çevre maliyetleri için örgütlere yapılan dönemsel başvurular, örgütler tarafindan takip edilen muhasebe programının olumsuz yönlerini ortaya çıkarır. $\mathrm{Bu}$ da örgütlerin gelir ve çevre yararlarını karşılaştırmalarına imkan verir.

Ürün, üretim, sistem ya da tesisle ilgili çevresel maliyetlerin açıklanması ve tanımlanması yönetim karalarının iyi bir şekilde uygulanması için önemlidir. Bu hedeflere ulaşmak için çevresel harcamaların azaltılması, gelirin arttırılması, mevcut veya gelecekteki çevresel performansın geliştirilmesi ve çevresel maliyetlere önem verilmesi gerekir. Bir işletmenin çevresel maliyetleri nasıl tanımlayacağı bu bilgiyi nasıl kullanacağına (örneğin maliyet dağıtımı, sermaye bütçeleme, işlem/ürün tasarımı diğer yönetim kararları) ve faaliyetlerin ölçülmesine ve kapsamına bağlıdır (EPA, 1995: 7).

Muhasebe bilgi sisteminde üretilen işletmeye ilişkin bilgiler, evrensel bir dille, işletme ile ilgili gruplara sunulur. Mevcut ve potansiyel yatırımcılar, çalışanlar, borç verenler, satıcılar, diğer ticari alacaklılar, müşteriler, devlet ve toplum bu bilgilerin kullanıcılarıdır ve bu kullanıcılara mali tablolar hazırlanır ve sunulur (Sevilengül, 2005: 10). Doğal kaynakları tüketen bir varlık olarak işletmeler çevresel etkileri ve çevreyi koruma faaliyetleri hakkında topluma bilgi sağlama sorumluluğuna sahiptir (Ulusan, 2009: 183). Çevresel faaliyetlerin işletme faaliyetlerinde gittikçe artması, çevresel faaliyetlere ilişkin bilgilerin önemini arttırmakta ve kayıtlarda ayrı ve belirgin bir şekilde izlemeyi gerektirmektedir (Kırlığlu ve Can, 1998: 118). Ayrıca işletmelerin rekabette üstünlük sağlamaları için de kendi performansı ile ilgili bilgileri ilgili kişilere iletmesi gerekir. Özellikle işletme ile ilgili yatırım yapmak isteyen kişilerin ilgileri işletmeye yönlendirilmesi işletmenin temel amaçlarındandır. Performansının ve yaptığı faaliyetlerin bir göstergesi olarak çevre raporları da yatırımcılara işletmeye yönelmeleri konusunda pozitif katkı yapmaktadır (Kaya ve Varıc1, 2008: 212).

İşletmeler, mamul ve süreç tasarımı, mamul karması oluşturulması, tesisi konumlandırma, satın alma, sermaye yatırımları gibi kararlarında diğer maliyetlerin yanında çevresel maliyetleri de göz önüne almalıdırlar. Ayrıca risk yönetiminde, performans değerlendirmesinde, maliyet dağıtım ve kontrolünde ve mamul fiyatının belirlenmesinde çevresel maliyetleri kullanmalıdırlar (Özbirecikli 2000: 15-21). 
Çevresel sorunların her geçen gün önem kazanmasıyla, işletmelerin çevresel maliyetlerin yönetilmesini dikkate almaları bir zorunluluk haline getirmiştir. Geleneksel muhasebe sistemleri üretim maliyetlerini hesaplarken çevre kirliliğin önlenmesi amacına yönelik maliyetleri de, geri dönüşüm süreçlerini ve yasal düzenlemeleri dikkate almalıdır. Bu noktada işletmeler geleneksel üretim anlayışına bağlı kalarak mal ve hizmetlerin sadece üretim noktasında maliyetlerin yönetilmesine yoğunlaşmamalıdır, ayrıca mal ve hizmetlerin üretim sürecinden sonraki aşamalarda yer alan atıkların kontrolü, yok edilmesi, kirliliğin önlenmesi amacına yönelik maliyetleri, geri dönüşüm süreçlerinde yaşanacak değişimleri dikkate alarak çevresel maliyet yönetimini uygulamalıdırlar.

\section{2. ÇEVRESEL MALIYET YÖNETIMININ BAŞARILMASINDA ÇEVRE YÖNETIM} SİSTEMLERINIIN ROLÜ

İşletme yöneticileri çevresel uygunluğu göz önünde tutarak alacakları kararlarda ve yönetim stratejilerinde, mamul çeşitliliğini ve fiyatlamasını, üretim girdilerinin seçilmesini, kirliliği önleme projeleri ve atık yönetimi seçeneklerinin değerlendirilmesini, çevre maliyet bilgilerine göre vereceklerdir (Akün, 1999: 153). Genellikle üreticiler, yaşam seyri maliyetlerine kar maksimizasyonu açısından bakma çevreye özen göstermeme gibi bir anlayış vardı. Çevreyle ilgili çeşitli organizasyonlar ve yasal düzenlemeler, işletmeleri çevre konusunda duyarlı davranmaya ve karar alma süreçlerinde çevresel faktörleri de dikkate almaya yöneltmiştir. Çevrenin korunması konusunda tüketicilerden gelen talepler de, işletmeleri çevreye karşı daha duyarlı olmaya yönlendirmektedir.

ISO 14001 "Çevre Yönetim Sistemleri Özellikler ve Kullanım Kılavuzu", üretim/hizmet gerçekleştirmenin beraberinde çevreyi korumayı ve çevre etkilerini minimize etmeyi amaçlayan kuruluşlara çevre etkilerinin tespitinden başlayarak, bunların nasıl azaltılabileceği, oluşması muhtemel etkiler için nasıl önlem alınabileceği ile ilgili belirlenmiş prosesler getiren bir sistemdir (Ertuğrul ve Şavlı, 2013: 227). ISO 14001 Standardını temel alan bir çevre yönetim sistemi her tip ve büyüklükteki işletmenin kendi ürün, hizmet ve faaliyetlerinin çevre üzerindeki etkilerini kontrol etmesine yardım eden bir yönetim aracıdır (Korul, 2003: 107). ISO 14001 ÇYS Standard1; çevre performans standard1 olmayıp, çevre yönetim standardı olduğuna dikkat edilmelidir. ISO 14001 ÇYS Standardı, performans düzeyleri ve kriterleri tanımlamamakta, işletmeye, işletmenin uyması gereken yasalar ve işletmenin gereklilikleri dikkate alınarak, kendi performans araçlarını ve hedeflerini belirleme olanağını sağlamaktadır (Yüksel, 2003).

ISO 14001, halihazırda, işletmenin performansını etkilemeden sadece organizasyonun çevre performansının geliştirilmesinde kullanılmaktadır. İşletmelerin bir adım ilerisini görerek, ISO 14001 standardının sadece yasal düzenlemeler için değil, kurum imajı gibi kendilerine sağlayacağı rekabet üstünlükleri gibi amaçlar için de gerekli olduğu kabul edilmelidir. Bu açıdan bakıldığında, ISO 14001 Sertifikasyonu, sürdürülebilir kalkınma, değer katma ve kalite temelinde paydaşların memnuniyeti ve 
ilişkilerin geliştirilmesi konularında işletmelere, operasyonel, yönetimsel ve rekabet üstünlükleri getirebilecek standartlar olarak görülmelidir (Küçük, 2009: 53,54).

Çevre yönetimi, ekolojik çevreyi karar alma süreçlerinde önemli bir unsur olarak dikkate alan, faaliyetlerinde çevreye verilen zararı minimuma indirmeyi veya tamamen ortadan kaldırmayı amaç edinen bu çerçevede, üretim süreçlerini değiştiren, ekolojik çevrenin korunması felsefesini işletme kültürüne yerleştirmek için çabalayan, sosyal sorumluluk kapsamında topluma karşı görevlerini yerine getiren işletmelerin benimsediği bir anlayıştır (Nemli, 2001: 212-213). Çevre yönetimi, merkezi insan olan ve insanın da bir öğesi olduğu bütünlüğün, canlıların zarar görmesini önlemeyi amaçlayan, tutarlı eylemlerin oluşturduğu bir etkinlik alanıdır. Çevre yönetimi çalışmalarıyla, çevrenin, insanoğlunun hangi faaliyetleriyle, hangi doğrultuda, hangi şiddette değiştirildiği ve kimler tarafından nasıl önleneceğinin belirlenmesi, çevre sorunu sayılan oluşumların engellenmesi ve çözümlenmesine yönelik amaçların, politika ve stratejilerin bu belirlenen hareketle geliştirilmesi ve çeşitli yollarla hayata geçirilmesi hedeflenmektedir (Ekici, 2010: 30).

Çevre yönetimi sistemi, işletme kararlarında çevrenin sürekli göz önünde bulundurulması, kararların uygulanması için uygun sistem ve süreçler geliştirilmesini ifade eder. Çevre yönetimi sistemi, bir kontrol sistemi değildir. İşletmenin çevre konusundaki sorumluluklarına cevap verici ve aynı zamanda riskleri azaltıcı, pazar imkânlarını artırıcı işlevlere sahiptir. Çok sayıda firmanın faaliyet raporlarında, çevre yönetim sisteminin, çevre koruma yanında, ekonomik başarılar da getirdiği belirtilmektedir (Çevre Yönetim Sistemi Rehberi, 2008).

Çevre yönetim sisteminin gerekliliklerinin karşılanması, işletmelerin çevre performansının gelişmesine olanak sağlamaktadır (Yüksel, 2010: 25). Çevresel performansın hesaplanması; çevreye dönük yapının oluşturulmasında işıletmeler için çeşitli aşamalarda çok etkili bir araçtır. Konu ile ilgili standart bir düzenlemenin olmaması işletmeler için çevresel performanslarını belirlemede sorun oluşturmaktadır. İşletmelerin kendi çevresel faaliyetlerini değerlendirmelerinde kullanılabilecek yöntemler olarak çevresel etki matrisi, yaşam döngüsü analizi, yönetici tutum anketleri, çevre performansının puanlanması ya da endekslenmesi kullanılabilir (Akıncı ve Akıncı, 2010). Çevre performansını ölçme değişkenleri olarak; çevreye dönük yönetim ve eğitim faaliyetleri, mevzuata uygunluk (denetimlere uyulmama kayıtları, şikâyetler, uyarılar, para cezaları ve diğer cezalar), kaynak tüketimi (enerji, su, alan, arazi, gereksiz bina, diğer sosyal kaynakların kullanımı vb), toz ve gaz emisyonu, gürültü dağılımı, denetim (uyumsuzluk raporları, gözlemlenen marjinal vakaların raporları), atık oluşumu, su tahliyesi, enerji, kaynaklardan maliyet tasarrufu sağlamak gibi faktörler kullanılabilir (Tam vd. 2006a: Tam vd. 2006b).

İşletmelerin çevresel performansları ile ilgili değerlendirilebilecek diğer bir araç da çevresel raporlardır. Çevresel raporlama bir işletmenin çevre üzerine etkileri, bu etkileri yönetme performansı ve 
ekolojik bakımdan sürdürülebilir kalkınmaya katkısı dahil çevresel performansı hakkındaki bilgilerin kamuya açıklanmasıdır. Proaktif çevre yaklaşımında işletmelerin çevresel bilgilerini açıklamalarıyla hem işletme düzeyinde hem de endüstri düzeyinde bir farkındalık yaratmak istenmektedir. İşletmelerin çevresel iletişim aracı olarak kullandığı çevresel raporlamaya doğru nispeten artan eğilim olduğu görülmektedir. Ancak, bu raporlar daha sıklıkla büyük işletmeler tarafından hazırlanmaktadır. Küçük ve orta ölçekli işletmelerin birçoğu bu raporların maliyetinin çok yüksek ve faydasının ise çok düşük olduğunu düşünmektedirler (Ulusan, 2009: 182-184).

Çevresel maliyetleri azaltmak ve kuruluşun çevresel performansını değerlendirmek ve güzelleştirmek için işletmelerin bu alanda kendi amaçlarını gerçekleştirmelerine imkan veren bir yöntem benimsemeleri gerekir. Çevresel performans bu noktada 'işletme faaliyeti ve çevre arasındaki etkileşimin ölçüsü’ olarak çevre performansının yönetim tarafından belirlenen hedefleri karşılayıp karşılamadığını belirlemek amacıyla sürekli, güvenilir ve doğrulanabilir bilgi sağlamak için tasarlanmış bir iç yönetim aracı olarak ele alır. Çevresel performans göstergeleri çevre performansını değerlendirme ve gelişim için potansiyel alanlar belirleme konusunda şirket yönetimini desteklemenin yanı sıra, veri ve bilgileri sentezlemekte ve sonuçları paydaşlar için tam olarak kullanılabilir hale getirmektedir (Cagno, Tardini ve Trucco, 2007: 20).Çevresel maliyetler ve çevresel performans işletme yönetimi için önemlidir. İşletme yönetiminde ve çevresel maliyetlerin ölçülmesinde önemli rol oynayan maddeler aşağıdaki gibi sıralanabilir (Özbirecikli ve Melek, 2002: 83).

> İşletme yönetiminin faaliyetlerle ilgili kısa dönemli değişikliklerden çok, daha yeşil (greener) bir üretim sürecine yatırım, üretim/mamul süreci ve/veya mamulün yeniden tasarımı gibi konulara yönelik kararları sonucu birçok çevresel maliyet önemli ölçüde azaltılabilir veya ortadan kaldırılabilir. Zira çevresel maliyetlerin önemli bir kısmı (örneğin, atık hale gelmemiş hammadde) üretim sürecine, sisteme ve mamule katma değer sağlamayabilir.

$>$ Çevresel maliyetler genel giderler hesabında izlenebilir veya belki de göz ardı edilebilir. Yani hesaba katılmayabilir.

D Birçok firma temiz teknoloji lisansı edinmek veya fire niteliğindeki yan ürünlerin satışı yoluyla gelir yaratmak suretiyle çevresel maliyetleri telafi edebileceklerini keşfetmişlerdir.

Çevresel maliyetlerin daha iyi bir şekilde yönetilmesi, işletmenin başarısında olduğu kadar, insan sağlığına önemli yararlar sağlanmasında ve çevresel performansın arttırılmasında da büyük paya sahiptir.

Müşteriler için çevresel açıdan tercih edilebilir mamul, hizmet ve üretim süreçleri rekabet avantaj1 sağlar. 
> Mamul ve üretim sürecine ilişkin çevresel maliyetlerin ve çevresel performansın bilinmesi hem mamul maliyetlerinin ve fiyatlarının daha doğru saptanmasına, hem de şirketin mamul, hizmet ve üretim süreçlerini çevresel açıdan daha tercih edilebilir bir şekilde tasarlamasına yardımcı olur.

$>$ Çevresel maliyetlerin ve çevresel performansın muhasebeleştirilmesi bir şirketin gelişmesini ve çevre yönetim sistemi (EMS- Environmental Management System) faaliyetlerini destekleyebilir. Böyle bir sistem yakın gelecekte uluslararası bağlantıları olan şirketler için (ISO 14001'den dolay1) bir zorunluluk haline gelecektir.

Çevresel yönetim sistemlerini benimseyip uygulayan işletmelerin çevresel performanslarının daha yüksek olacağı, bunun da ürün yaşam seyri kapsamında çevresel maliyet yönetimine olumlu katkılar sağlayacağ1 düşünülmektedir.

\section{3. ÜRÜN YAŞAM SEYRI MALIYETLEMESİ AÇISINDAN ÇEVRESEL MALIYET YÖNETIMMI}

Ürün yaşam seyri (product life cycle), pazarlama yönetiminde ürün stratejilerine yönelik bir yaklaşımı temsil etmektedir. Bu yaklaşıma göre; işletmeler yeni ürünlerinin pazara sunulmasından itibaren uzun bir süre pazarda kalmasını ve kar getirmesini isterler, buna bağlı olarak her ürünün süresi ve şekli önceden tam olarak bilinemeyen bir yaşam seyri vardır (Şakrak,1997: 86). Ürün yaşam seyri, bir mamul veya hizmete olan talebin zaman boyutu bağlamında gösterdiği eğilim veya yapı olarak tanımlanmaktadır. Pazara sunulan her mamulün pazara sunulmasıyla başlayan, kullanımı ve desteklenmesiyle devam edip, tasfiye edilmesiyle sona eren bir hayat süreci vardır (Karcıoğlu, 2000: 90). Ürün yaşam seyri (product life cycle), belirli bir ürün pazarında (product market), belirli bir ürün fikri için kârları ve endüstri satışlarını açıklayan bir kavramdır. Bu kavram, bütün ürünlerin insanlar gibi bir yaşam seyri olduğunu ve bu yaşam seyrinin de bir sonunun olduğunu belirtmektedir (Baybars, 1999: 416).

İşletmeler, pazara sundukları mamullerle pazarda uzun süre kalmak, pazarın kaymağını almak ve pazarda lider konuma gelmek istemektedirler. Pazarlama yönetiminde mamul stratejilerinin belirlenmesinde önemli bir kavram olan ürün yaşam seyri, işletmelerin pazara ilişkin hedeflerinin belirlenmesi ve gerçekleştirilmesinde önemli faydalar sağlamaktadır (Sevim, 2002; Karafakığlu, 2005: 131). Ürün yaşam seyri kavramı, işletmelerin geliştirdiği ve piyasaya sunduğu mamullerin çeşitli aşamaları ya da dönemleri içeren bir yaşam süresine sahip olduğunu ifade etmektedir (Sevim, 2002: 138). Ürün yaşam seyri maliyetleri bir ürünün ömrü boyunca beklenen tüm maliyetleridir.

Ürün yaşam seyri evreleri daha önceleri sunuş, büyüme, olgunluk ve düşüş olmak üzere dört temel evreden oluşmaktaydı. Daha sonraki yeni gelişmeler çerçevesinde, bu dört evreye planlama ve geliştirme, terk etme ve yenileme evreleri de eklendi (Sevim, 2002: 142). Böylece ürün yaşam seyri evreleri; planlama ve geliştirme, sunuş ve büyüme, olgunluk, gerileme, terk etme ve yenileme olmak üzere beş temel evreden 
oluştu. Bu temel evrelere bağlı olarak, bu yaklaşımın başlıca yararları aşağıdaki gibi sıralanmaktadır: (Şakrak,1997: 87)

$>$ Yaklaşım, ürün yaşamlarının sınırlı olduğunu gösterir.

> Yaşam seyri boyunca ürünlerin karlarının öngörülebilir bir seyir izlediğini açıklar

$>$ Her evrede ürünlerin farklı bir pazarlama, üretim, finansman vb. unsurları gerektirdiğini hatırlatır.

$>$ Ürün ve pazar dinamiklerini ortaya koyar

$>$ Bir planlama aracı olarak, her evrede alternatif pazarlama stratejilerini ortaya koyar.

$>$ Bir kontrol aracı olarak da işletmenin, ürün performansını, geçmişte pazara sunulmuş benzer nitelikteki ürünlerle karşılaştırarak, ölçme olanağı verir.

Ürün yaşam seyrindeki kısalmaya bağlı olarak yeni ürünlerin tasarım ya da geliştirilmesi için gereken zaman aralıkları da oldukça kısalmıştır. Bu değişim, toplam ürün maliyetleri içindeki ürün tasarım ve geliştirme maliyetlerinin oransal olarak artmasına neden olmuştur. Günümüzde, ürün yaşam seyrine ait toplam maliyetlerin önemli bir bölümü, üretim öncesi aşamalarda oluşmaktadır (Karakaya,1999: 106). Üretim öncesi aşama ürün fikrinin ortaya çıkmasıyla başlamaktadır. Bu aşamada, üretilecek ürünle ilgili tüketicilerin tercihlerini ortaya koyacak pazar araştırması yapılmaktadır. Mühendisler tedarikçiler ve tasarımcı ekibi arasındaki işbirliğinin önemi de bu aşamada ortaya çıkmaktadır. Çünkü bu ekiplerin işbirliği ile üretim süreci ve ürünün bileşimini oluşturan parçalar belirlenecektir. Üretim öncesi aşamalarda verilecek kararların neticesinde ürünün tüm yaşam seyri boyunca göstereceği performansı da belirlenmiş olacaktır. Ürün tasarlanırken en önemli unsur, parçaların mümkün olduğu kadar standart olması ve mümkün olduğunca en az sayıda parça kullanılmasıdır. Bir ürünün tasarımı ne kadar iyi yapılırsa, o ürünün üretim aşamasında ve üretim sonrası aşamalarda tasarımdan kaynaklanan hataları düzeltmek için katlanılacak ek maliyetler de en düşük seviyeye indirilmiş olacaktır. Ayrıca üretime geçildikten sonra tasarımda önemli değişiklikler yapmak, üretime geçmeden önce tasarımda değişiklik yapmaya göre daha maliyetli olacaktır (Erden: 2005: 206). Üretim maliyetlerinin \% 80'nin mamül yaşam seyri açısından tasarım ve süreç planlaması gibi üretim öncesinde belirlendiği (Karakaya, 2006: 716) benzer şekilde ürün ile ilgili çevresel maliyetlerinde büyük oranda tasarım aşamasında karara bağlandığını söyleyebilir.

Ürün yaşam seyri kavramını maliyet yönetimi açısından iki grupta toplayabiliriz: Üretici açısından ürün yaşam seyri, tüketici açısından ürün yaşam seyri. Üretici açısından ürün yaşam seyri dört aşamadan oluşmaktadır: Ürün fikrinin oluşturulması, tasarım aşaması, üretim aşaması, satış sonrası aşamalar. Tüketici açısından ürün yaşam seyri, beş aşamadan oluşmaktadır: Satın alma aşaması, kurulum (montaj) aşaması, destek aşaması, bakım-onarım aşaması, elden çıkarma aşaması (Doğan, 2000: 92-93). Ürün yaşam seyri 
maliyetlemesi, bir ürünün toplam yaşam seyri boyunca maliyetlerini hesaplamak için kullanılan bir süreçtir. $\mathrm{Bu}$ süreç, sermaye bütçelemesi kararları veya toplam yaşam maliyeti düşük kaliteli ürünler üretmek gibi çeşitli yönetim araçlarında kullanılabilir. Bu maliyetler; iki sınıfa ayrılır, üretici ve kullanıcı maliyetleri olmak üzere. Üretici maliyetleri; üreticinin maruz kalacağı, ürün yaşam seyrindeki tüm maliyetleri içerirken kullanıcı maliyetleri ise; kullanıcının maruz kalacağı alım, kullanım, bakım ve elden çıkarma maliyetlerini içerir (Sakurai,1996: 163). Ürün yaşam seyri kapsamında üreticinin maruz kalacağı çevresel maliyetler ve tüketicilerin maruz kalacağı çevresel maliyetler belirlenmelidir.

Ürün yaşam seyri maliyetlemesinin temel amac1; ürünün planlanması, tasarımı, pazarlanması, dağıtımı, işlenmesi, bakımı ve elden çıkarılması gibi işletmeyi uzun dönemde rekabet ortamında avantajlı duruma gelmesine neden olan hareket ve kararların alınmasıdır (Sakurai,1996: 168). Çevresel maliyetlere katlanarak çevreye duyarlı ürünler tasarlayıp çevreye duyarlı malzemeler kullanarak üretim yapan, yine çevreye duyarlı ambalaj malzemeleri kullanan işletmeler bu durumu müşterilere raporlayıp, anlatabildiği sürece daha fazla rekabet avantaj1 elde edebilecektir.

Ürün yaşam seyri maliyetlerinin, hem üretici açısından hem de tüketici açısından değerlendirilmesi, üreticinin bir ürünün yaşam seyri maliyetini hem kendi açısından hem de tüketici açısından hesaplamak zorunda olduğunu göstermektedir. Üretici, bir ürünün veya hizmetin üretici bakış açısıyla toplam yaşam seyri maliyetini hesaplamadan önce, tüketici için toplam yaşam seyri maliyetini hesaplama durumundadır (Gersı1, 2006: 70). Aynı şekilde üretici firma hem kendisi açısından hem de tüketici tüketici açısından ortaya çıkabilecek çevresel maliyetleri hesaplamalı ve planlamalıdır.

Şekil : 1 ürün yaşam seyri çevresel maliyetleri

\begin{tabular}{|c|c|}
\hline \multicolumn{2}{|c|}{ ÜRÜN YAŞAM SEYRI ÇEVRESEL MALIYETLER } \\
\hline Üreticinin katlanacağı çevresel maliyetler & Tüketicinin katlanacağı çevresel maliyetler \\
\hline ÜRETiCi ÇEVRESEL MALIYYTLERi & TÜKETICi ÇEVRESEL MALIYYTLERi \\
\hline Fikir aşamasında çevresel maliyetler & Satın alma aşamasında çevresel maliyetler \\
\hline Tasarım aşamasında çevresel maliyetler & Kurulum aşamasında çevresel maliyetler \\
\hline Üretim aşamasında çevresel maliyetler & Destek aşamasında çevresel maliyetler \\
\hline Satış sonrası aşamasında çevresel maliyetler & Bakım-Onarım aşamasında çevresel maliyetler \\
\hline & Elden çıkarma aşamasında çevresel maliyetler \\
\hline
\end{tabular}

Fikir: Bu aşamada üretilecek mamül fikrini ortaya koymaya yönelik hammadde sağlamak ve pazar araştırmasını yapmak için katlanılan maliyetlerdir. Bu noktada, üretilecek ürünle ilgili tüketicilerin tercihlerini ortaya koyacak pazar araştırması yapılmaktadır. Mühendisler-tedarikçiler ve 
tasarımcı ekibi arasındaki işbirliğinin önemi de bu aşamada ortaya çıkmaktadır. Çünkü bu ekiplerin işbirliği ile üretim süreci ve ürünün bileşimini oluşturan parçalar belirlenecektir. (Erden: 2005: 206).

> Tasarım: Bu aşamada çevreye en az zarar verecek şekilde tasarlanması için katlanılan maliyetlerdir. Örneğin; ses gürültü kirliliğini önlemek için katlanılan maliyetler. Bu aşamada yeni ürün tasarımı yapılırken, eklenen her ilâve parçanın ek bir maliyet getirdiği düşünülerek, tasarımda sadeliğe ve müşteri isteklerine tam olarak uymasına dikkat edilmelidir. Ayrıca, aynı işi görebilecek parçalardan, daha düşük maliyetli olanı tercih edilmelidir (Coşkun, 2002, s.33).

> Üretim: Üretici bu aşamada üretilecek ürünlerin ve hizmetlerin çevreye olumsuz etkilerini azaltan üretim araçlarının kullanımı, işletmenin çevre ile olan ilişkisinin yöntemlerini, faaliyet ölçeklerini ve ürün tasarımlarını kapsayan önemli bir süreçtir (Klassen, 2000; 129). Bu aşamada çevreye zarar vermeyen malzemelerin kullanılması üretim sonucunda ortaya çıkacak kirli atıkların ve çevreye bırakılmaması için katlanılan maliyetler şeklinde yorumlanabilir.

Satış sonrası: Geri dönüşüm imkanı olan malzemelerin kullanılmasının getirdiği ek maliyetlerdir. Satış sonrası aşamaların maliyetleri, toplam ürün yaşam seyri maliyeti önemli bir pay almaktadır. Özellikle bu aşamanın sonunda ortaya çıkan elden çıkarma maliyetleri, ürünün yararlı ömrünün sona ermesiyle ilgili zararlı etkilerin (çevresel etkiler) elemine edilmesiyle ilgili maliyetleri de içermektedir. Nükleer atık ve diğer zehirli kimyasallar gibi elden çıkarılması çevreye zararlı ürünler çok yüksek maliyetlere neden olmaktadır. Satış sonrası aşamalarda önemli bir diğer maliyet kalemi lojistik maliyetleridir (Gers11,2006: 88 ).

> Satın alma: Bu aşamada tüketicini mamülü almaya yönelik kabul gördüğü satın alma bedeli, vergiler, nakliye ve kurulum giderlerinin oluşturduğu kategoridir (Lund, 1978).

> Destek: Bu aşamada personel maliyetleri (iş̧̧i bakım maliyetleri, diğer personel desteği, faaliyet ekibi ve yönetimi)

> Bakım onarım: Mamulün kullanımı aşamasında ortaya çıkacak arıza ve yıpranmalara karışı yapılacak harcamalar bu maliyet sınıfina girmektedir (Lund, 1978).

> Elden çıkarma: Bu maliyetler mamulün yararlı ömrünün sonunda, kullanılma imkanı olmayan mamulün ortadan kaldırılması veya elden çıkarılması için katlanılan maliyetlerden oluşmaktadır (Lund, 1978).

Toplumların refah düzeyleri arttıkça çevreye duyarlı ürün talepleri artmakta, bu durum çevresel maliyetleri gönüllü olarak yüklenmelerine neden olacağı için çevresel maliyet yönetimini de kolaylaştıracaktır.

Ürün yaşam seyri maliyet sistemi, ürünün tasarım aşamasında meydana gelen maliyetlerin, uzun vadede karları maksimize edeceği, ürünün yaşamı boyunca maliyetleri düşüreceği, görünmeyen maliyetleri asgari düzeye indireceği ve maksimum müşteri memnuniyeti varsayımına dayanmaktadır (Sevim, 2002: 
138). Maksimum müşteri memnuniyetini sağlamak için çevresel maliyetlerin belirlenip yönetilmesi, raporlanması gerekir. Üretici tarafindan katlanılan çevresel maliyetler diğer paydaşlara iyi anlatılmalıdır. Çevre bilincinin artmasıyla birlikte işletmelerin çevreye yönelik hassasiyetlerini arttırmaya çalışan kanun koyucuların baskısı sonucunda normal mali raporlara çevresel üretim raporlarının da eklenmesi zorunluluğu doğmuştur.

İşletmelerin çevreye yönelik faaliyetlerini daha net görebilmek için çevresel raporlar yıllık mali raporlardan ayrı olarak da düzenlenebilir. Finansal nitelikli çevresel bilgilerin ayrıntılı olarak raporlandığı çevresel maliyet raporları, bilgi kullanıcılarının işletmenin çevresel maliyetleri hakkında daha kolay ve daha hızlı bilgi edinmesini sağlayabilir. Gün geçtikçe çevreye duyarlı tüketicilerin artması nedeniyle çevresel maliyetlere katlanılan üretici firmalar rekabet avantajı sağlayabilecektir.

Çevresel maliyetleri yönetebilmek için ürün yaşam seyri kapsamında üreticinin ve tüketicinin katlanacağı çevresel maliyetlerin bilimsel yöntemler kullanılarak belirlenmesi gerekmektedir.

\section{4. ÜRETİCI VE TÜKETİCI AÇISINDAN ÜRÜN YAŞAM SEYRİ MALİYETLERİ VE ÇEVRESEL MALIYETLER}

Üreticiler, yaşam seyri maliyetlerine kar maksimizasyonu açısından bakarken, tüketiciler ise fayda maliyet açısından bakmaktadır. Toplum ise, çevresel açsından bakarak, üretimden, ürünün kullanılmasından ve elden çıkarılmasından doğan çevresel maliyetlere odaklanmaktadır (Yılmaz ve Arı, 2011: 1). Toplum içerisine üretici ve tüketiciler de girdiğine göre çevresel maliyetler tüm paydaşlar açısından önemlidir.

Tüketici açısından ürünün yaşam seyri maliyetinin rakip ürünlere göre yüksek olması, o ürünün rakip ürünler karşısındaki rekabet gücünü olumsuz etkileyecektir. Tüketici, ürün yaşam seyri maliyeti daha düşük olan ürüne yönelme eğiliminde olacaktır. Pazarlama bakış açısıyla ürün yaşam seyrinin tüm aşamaları bir ürünün üretim sürecini ifade etmektedir. Dolayısıyla bu aşamalarda ortaya çıkan maliyetler üretim maliyetleri kapsamındadır. Ancak, günümüzde hakim olan yeni maliyet muhasebesi yaklaşımları bir ürünün sadece üretim sürecini değil, üretim öncesi ve üretim sonrası aşamalarını da kapsamaktadır. Bu yaklaşımlardan biri olan ürün yaşam seyri maliyetleme yöntemi de, bir ürünün tüm yaşam seyri boyunca ortaya çıkan maliyetleri, hem tüketici hem de üretici açısından en düşük seviyeye indirme amacını taşımaktadır (Karakaya, 2004: 576). Tüketici açısından yaşam seyri çevresel maliyetleri yüksek olan ürünlere talep azalacağ için tüketicilerin katlanacağı çevresel maliyetlerin mümkün olduğunca düşürülmesi gerekir.

Ürünün yaşam seyri tasarım aşamasından başlamakta, ilk madde ve malzeme temini, üretim süreci, satış sonrası aşamaları ile devam etmekte, elden çıkarma ve yeniden kullanma aşamalarıyla döngüsünü tamamlamaktadır. Ürün yaşam seyri düşüncesinin bu bakış açısıyla ele alınması birçok maliyet unsurunun 
da ortaya çıkmasına neden olmaktadır. Üretilen ürünle sadece üreticiler ve tüketiciler ilgilenmemekte kamu kuruluşları, çevrenin yönetimi ve korunması ile ilgili kuruluşlar da taraf olmaktadır. Ayrıca, üretici sadece üretim sürecinden sorumlu olmamakta, kullanılan ilk madde ve malzeme ve atıklar da üreticinin sorumluluğuna girmektedir. Dolayısıyla, üretici üzerindeki sosyal sorumluluk baskısı da artmaktadır. Tüketici açısından ise bir ürünün satın alınmasında sadece satın alma fiyatının değil, o ürünün kullanım süresince ortaya çıkaracağı maliyetlerin dikkate alınmasının gerekliliği olduğudur (Ersoy, 2002: 51). Özellikle elden çıkarma maliyetleri, ürünün yararlı ömrünün sona ermesiyle ilgili zararlı etkilerin (çevresel etkiler) ilgili maliyetleri de içermektedir. Nükleer atık ve diğer zehirli kimyasallar gibi elden çıkarılması çevreye zararlı ürünler çok yüksek maliyetlere neden olmaktadır. Satış sonrası aşamalarda önemli bir diğer maliyet kalemi lojistik maliyetleridir. Lojistik maliyetleri ürün yaşam seyri analizinde daha ayrıntılı incelenecektir. Toplam ürün yaşam seyri maliyetlerinin anlaşılmasıyla, bir ürünün tasarım ve üretim süreci daha etkin bir şekilde düzenlenebilir ve satış sonrası aşamaların maliyetleri de düşürülebilir (Atkınson vd, 1997: 7 ).

Ürün tasarımı, işletmenin üretimini yapacağı ürünün özelliklerini belirleme amacıyla yapılan işlemlerdir. Bu aşamadaki faaliyetlerin yürütülebilmesi için öncelikle yüksek düzeyde nitelikli işgücüne ve teknolojik donanıma ihtiyaç duyulmaktadır (Tekin,2000: 107).

Çevreye duyarlı üretim, çevreye etkileri düşük girdiler kullanan, yüksek verimliliğe sahip olan ve çok az veya sıfır atık içeren ve kirlilik oluşturmayan üretim süreçlerini kapsamaktadır (Atlas ve Florida, 1999: 13; Akt. Yavuz, 2010: 77). Bu tanıma göre çevreye duyarlı üretim, atık ve kirliliğin engellenmesi veya azaltılmasını, geri dönüşümü ve yeşil ürün tasarımını içeren faaliyetler ve süreçler olarak ele alınmaktadır. Diğer yandan, üretim girdilerinde değişikliklere gitmek, çevreye duyarlı üretim yapan işletmeler için önemli kazançlar sunabilmektedir (Yavuz, 2010: 77). Yapılan bir araştırmada işletmelerin, atıklarını azaltmak için geri dönüşüm, yeniden üretim gibi seçeneklerden uzun süredir yararlanmakla birlikte güvenli üretimi destekledikleri ve aynı zamanda çevreye duyarlı üretimin yeni gelişmeler arasında olduğu görülmüştür (Yüksel, 2003: 2). İşletmelerde çevre duyarlılığ1 ve bu doğrultuda yapılan üretim son yıllarda hızlı şekilde artmaktadır. İşletmeler, hem çevreye olan duyarlılıklarını kanıtlamak hem de tüketicilerinin bu yöndeki taleplerini karşılamak amacıyla çevreye duyarlı üretim teknolojileri kullanmaktadırlar (Cihangir vd.2006:1, 2006:1). İşletmelerin çevreye karşı sorumlulukları kapsamında üretim yönetimindeki kararlarında da çevre konularına verilen önem her geçen gün artmaktadır. Günümüzde işletmelerin, üretim/işlemler yönetimine ilişkin kararlarında çevre konularını artık dikkate almaları gerekmektedir (Yüksel, 2003: 2).

Tüketiciler tarafından talep edilen ürünün tüketicilerin beklentilerine uygun fiyatta, uygun kalitede, uygun zaman ve uygun yerde olmasını sağlamaktır. Dolayısıyla, pazarlamanın ürünün tasarımına ilişkin 
değerlendirmeleri öncelikle dikkate alınması gerekmektedir (Tekin: 2000: 109). Günümüzde refah düzeyinin gelişmesi ile birlikte tüketiciler çevreye duyarlı çevre dostu ürünler talep etmektedirler. Bu talebin karşılanması gerekir. Ayrıca çevre dostu ürünlerin üretimi bazı düzenlemeler tarafından da desteklenmektedir.

Tasarım aşamasının öneminin artması, bu aşamada sağlıklı maliyet hesabının yapılmasını da zorunlu hale getirmektedir. Tasarım aşamasında oluşan veya oluşacak maliyetleri belirlemede tasarım anında maliyet hesaplama kavramı ortaya çıkmaktadır. Tasarım anında maliyet hesaplama kavramının en temel amacı, tasarımcıya ihtiyaç duyduğu anda ve ihtiyaç duyduğu maliyet bilgilerinin sunulmasıdır. Tasarım anında maliyet hesaplama ile bir ürünün üretim aşamasına geçilmeden maliyetleri yönetme imkânına sahip olunmaktadır. Tasarım anında maliyetleme kavramının perspektifi ürün yaşam seyrinin sonuna kadar uzanmaktadır. Tasarım anında maliyetleme ile bir ürünle farklı tasarım alternatiflerinin maliyetlerde ne gibi değişimlere yol açabileceği belirlenmektedir. Tasarım anında maliyet hesaplama, hedef maliyet yönteminin maliyet hedefine yönelik tasarım yapma amacının gerçekleştirilmesinde önemli bir araç olmaktır (Ceren, 2003: 4-6). Tasarım aşamasında çevresel maliyetlerin belirlenmesi, tahmin edilmesi ve bu maliyetlerin fiyatlara yansıtılıp yansıtılamayacağı, tüketicilerin verebileceği tepkiler iyi hesaplanmalıdır. Bu şekilde çevresel maliyetlerin yönetimi de kolay olacaktır.

Tasarım aşamasında çevreye duyarlı ürünlerin tasarlanması gerekir. Bu noktada çevresel maliyetlerin belirlenmesi, hesaplanması çevresel maliyet yönetimini başarılı kılacaktır. Ürün yaşam seyri düşüncesi çevresel tasarımın esasıdır. Bu açıdan çevresel maliyet yönetimi çok önemlidir. Çünkü ürünleri sadece üretim esnasında değil, aynı zamanda bu önemli aşamanın öncesinde ve sonrasında da çevresel etkilere sahiptir.

Çevreye duyarlı yönetim anlayışı ile işletmelerin çevresel sorumluluk duygusu ile faaliyet göstermelerini ifade etmektedir. Başka bir ifadeyle, çevrenin korunması ile ekonomik büyüme kavramlarının uzun dönemli ve birlikte düşünülmesi esasına dayanan sürekli bir süreci ifade etmektedir (Akatay ve Aslan, 2008: 318). Çevreye duyarlı yönetim her tür işletme ve organizasyonun çevresel performansını yönetme olarak ifade edilmiştir. Bir başka tanıma göre ise, şirket çevreciliği olarak adlandırılan çevreye duyarlı yönetimi, çevreyle ilgili konuların işletme tarafindan anlaşılması ve konuların karar alma süreci ile bütünleştirilmesi olarak ifade edilmektedir. Ayrıca, çevreyle ilgili konuların stratejik planlama ve strateji oluşturma süreciyle bütünleştirilmesi olarak da kabul edilmektedir (Akdoğan, 2003: 95). 


\section{SONUÇ VE ÖNERILER}

İşletmeler faaliyetleri gereği varlıklarını devam ettirebilmek için doğal çevrede var olan kaynakları kullanmaktadırlar. Sanayileşme hareketi ile beraber artan tüketim ve üretim olanakları sonucu işletmeler rekabet avantajı sağlamak için doğal kaynakların bilinçsizce ve sorumsuzca kullanılması doğal dengenin giderek bozulması çevre kirliliğine yol açmakta ve canlı yaşamını tehdit etmektedir. Bu faaliyetleri sonucu ortaya çevre kirliliği ve çevre sorunları doğmaktadır. Bu noktada bu olumsuz durumun azaltılmasında ve önlenmesinde işletmelere büyük görevler düşmektedir.

Çevresel sorunların her geçen gün önem kazanmasıyla, işletmelerin çevresel maliyetlerin yönetilmesini dikkate almaları bir zorunluluk haline getirmiştir. Geleneksel muhasebe sistemleri üretim maliyetlerini hesaplarken çevre kirliliğin önlenmesi amacına yönelik maliyetleri de, geri dönüşüm süreçlerini ve yasal düzenlemeleri de dikkate almalıdır. Bu noktada işletmeler geleneksel üretim anlayışına bağlı kalarak mal ve hizmetlerin sadece üretim noktasında maliyetlerin yönetilmesine yoğunlaşmamalıdır, ayrıca mal ve hizmetlerin üretim sürecinden sonraki aşamalarda yer alan atıkların kontrolü, yok edilmesi, kirliliğin önlenmesi amacına yönelik maliyetleri, geri dönüşüm süreçlerinde yaşanacak değişimleri dikkate alarak çevresel maliyet yönetimini uygulamalıdırlar. Çevresel yönetim sistemlerini benimseyip uygulayan işletmelerin çevresel performanslarının daha yüksek olacağı, bunun da ürün yaşam seyri kapsamında çevresel maliyet yönetimine olumlu katkılar sağlayacağı düşünülmektedir.

Günümüzde dünya kamuoyunda gelişen bu çevre bilinci ve duyarlılı̆̆ı, her kuruma olduğu gibi işletme yönetimlerine de büyük sorumluluklar yüklemektedir. Buna göre, 21. yüzyılda işletmeler yeşil olmayı (çevreciliği) bir felsefe, hatta bir hayat tarzı biçimine getirmekten sorumludurlar. Bu gelişmeler, 21.yüzy1l işletmeciliğinin, küresel gerçeğe yönelik yalın, esnek, bilgiye ve sürekli değişime dayalı çok yönlü özellikleri olduğu görülmektedir. Çevreye duyarlı yönetim tarzına geçiş ihtiyacı, bir bakıma 20. yüzyılın bitişiyle başlamıştır (Usta, 2007: 18).

Ürünün yaşam seyri tasarım aşamasından başlamakta, ilk madde ve malzeme temini, üretim süreci, satış sonrası aşamaları ile devam etmekte, elden çıkarma ve yeniden kullanma aşamalarıyla döngüsünü tamamlamaktadır. Ürün yaşam seyri düşüncesinin bu bakış açısıyla ele alınması birçok maliyet unsurunun da ortaya çıkmasına neden olmaktadır. Üretilen ürünle sadece üreticiler ve tüketiciler ilgilenmemekte kamu kuruluşları, çevrenin yönetimi ve korunması ile ilgili kuruluşlar da taraf olmaktadır.

İşletmelerde ürün hatlarının gelişmesine kullanılan teknolojilerin değişmesine, ürünlerin hayat seyrinin kısalmasına, küresel rekabet koşullarının farklılaşmasına ve bilgi teknolojilerindeki büyük değişikliklere cevap vermek amacıyla, yöneticilerin daha etkin ve zamanında bilgi sunabilen bir maliyet sistemi geliştirmeleri zorunlu olmuştur. İşletmeler, mamul ve süreç tasarımı, mamul karması oluşturulması, 
tesisi konumlandırma, satın alma, sermaye yatırımları gibi kararlarında diğer maliyetlerin yanında çevresel maliyetleri de göz önüne almalıdırlar.

Ürün yaşam seyri çevresel maliyetlerinin, hem üretici açısından hem de tüketici açısından değerlendirilmesi, üreticinin bir ürünün yaşam seyri çevresel maliyetlerini hem kendi açısından hem de tüketici açısından hesaplamak zorunda olduğunu göstermektedir. Üretici, bir ürünün veya hizmetin üretici bakış açısıyla toplam çevresel yaşam seyri maliyetini hesaplamadan önce, tüketici için toplam çevresel yaşam seyri maliyetlerini hesaplamak durumundadır.

Ürün, üretim, sistem ya da tesisle ilgili çevresel maliyetlerin açıklanması ve tanımlanması yönetim karalarının iyi bir şekilde uygulanması için önemlidir. Bu hedeflere ulaşmak için çevresel harcamaların hesaplanması, gelirin arttırılması, mevcut veya gelecekteki çevresel performansın geliştirilmesi ve çevresel maliyetlere önem verilmesi gerekir.

Üretici tarafından katlanılan çevresel maliyetler diğer paydaşlara iyi anlatılmalıdır. İşletmelerin rekabette üstünlük sağlamaları için kendi performansı ile ilgili bilgileri ilgili kişilere iletmesi gerekir. Özellikle işletme ile ilgili yatırım yapmak isteyen kişilerin ilgileri işletmeye yönlendirilmesi işletmenin temel amaçlarındandır. Performansının ve yaptığı faaliyetlerin bir göstergesi olarak çevre raporları da yatırımcılara işletmeye yönelmeleri konusunda pozitif katkı yapmaktadır. Çevre bilincinin artmasıyla birlikte işletmelerin çevreye yönelik hassasiyetlerini arttırmaya çalışan kanun koyucuların baskısı sonucunda normal mali raporlara çevresel üretim raporlarının da eklenmesi gerekli hale gelmiştir. İşletmelerin çevreye yönelik faaliyetlerini daha net görebilmek için çevresel raporlar yıllık mali raporlardan ayrı olarak da düzenlenebilir. Finansal nitelikli çevresel bilgilerin ayrıntılı olarak raporlandığı çevresel maliyet raporları, bilgi kullanıcılarının işıletmenin çevresel maliyetleri hakkında daha kolay ve daha hızlı bilgi edinmesini sağlayabilir. Gün geçtikçe çevreye duyarlı tüketicilerin artması nedeniyle çevresel maliyetlere katlanılan üretici firmalar rekabet avantajı sağlayabilecektir.

\section{Kaynakça}

ABDÜSSEYYİD, N., Sultan, E. ve Yusuf, Z. (2007). Çevre Muhasebesi: Muhasebe Birlik Sistemindeki Çevre Bilgileri Beyanının Öneri Çerçevesi, Irak Bilimsel Akademi Dergisi, cilt: 22, Sayı: 5: A58-A70

AKATAY, Ayten .,Aslan, Ş. (2008). Yeşil yönetim ve işletmeleri ISO 14001 sertifikası almaya yönelten faktörler. Dokuz Eylül Üniversitesi Sosyal Bilimler Enstitüsü Dergisi, 1(10), 313-339.

AKDOĞAN, A. (2003). Çevreye duyarl yönetim ve işletmecilik. Kayseri: Kayseri Ticaret Odası Yayınları.

AKINCI S. K. ve Akıncı, M. M. (2010). ,Sürdürülebilir Kalkınmaya Katkı Bağlamında Örgütlerin Çevresel Performansları ve Performans Değerlendirme Teknikleri` ${ }^{\circ}$. Atatürk Üniversitesi İktisadi ve İdari Bilimler Dergisi, Cilt: 24, Say1: 1, 193-207.

AKÜN, Lerzan (1999); "Çevre Muhasebesi; Genel Bir Bakış”, Muhasebe Bilim Dünyası Dergisi, Cilt:1, Sayı: 1, ss.153-155.

ATKINSON Anthony A, Rajiv D. BANKER, Robert S. Kaplan, S. Mark YOUNG, Management Accounting, 7th, Prentice Hall, USA, 1997. 
ATLAS, M., ve Florida, R. (1999). Green manufacturing. In C. Dorf (ed.) The technology management handbook (pp. 85-88). CRC Press, 13.

BAŞARAN, D. (2009). ISO 14001: 2005 çevre yönetim sisteminin çalı̧̧anlar tarafindan benimsenmesi ve çevre bilinci gelişimine etkisinin araştırılması. (Yüksek lisans tezi). Dokuz Eylül Üniversitesi Sosyal Bilimler Enstitüsü, İzmir.

CAGNO, E., Tardini, L., \& Trucco, P. (2007). EPIDesign: integrating corporate strategies into the development process of an environmental performance evaluation system. Strategic sustainability. The state of the art in corporate environmental management systems. Greenleaf Publisher, Sheffield, 20-42.

CEREN Yunus, "Hedef Maliyetleme Yöntemini Destekleyici Bir Enstrüman Olarak Ürün Gelistirme ve Tasarım Anında Maliyet Hesaplama”, Muhasebe Bilim Dünyası Dergisi, Cilt:5 Sayı:4, 2003, s.4,6.

CİHANGíR, M., Küçük, F., \& Türkal, H. (2006). Çevreye duyarlı üretim sistemi uygulayan işletmelerde sistemin getirdiği ilave maliyetlerle bu maliyetlerin ürünlere yüklenilmesinde karşılaşılan sorunların çözümüne yönelik bir değerlendirme. Akademik Bakış Uluslararası Hakemli Sosyal Bilimler E-Dergisi, (9), 1-7.

COŞKUN, Ali ve Nurcan KARACA (2008), "KOBİ'lerde Çevresel Maliyetlerin Sınıflandırılmasına Yönelik Bir Öneri: Metal İşleme Sektöründen Bir Uygulama”, Ekoloji Dergisi, s. 69: 59-65.

COŞKUN Ali, (2002-2003). "Stratejik Maliyet Yönetimi Aracı Olarak Hedef maliyetleme”, Akademik Araştırmalar Dergisi, Y11.4, S.15, Kasım 2002- Ocak 2003, s. 25-34.

Çevre Yönetim Sistemi Rehberi (2008). İstanbul Sanayi Odası Yayınları. No: 2008/11.

DOĞAN, Z. (2000). Maliyet Yönetiminde Yeni Bir Yaklaşım: Ürün Yaşam Seyri Maliyetleme Yöntemi, MÖDAV Muhasebe Bilim Dünyası Dergisi, Cilt:2, Sayı:1,Mart

EKİCI, U. (2010). Avrupa Birliği Kapsamında, ISO 14001 (Çevre Yönetim Sistemi) Değerlendirme Standardı ve Türkiye'deki Durum (Bir Alan Araştırması). Ege Üniversitesi Çevre Bilimleri Anabilim Dalı Yüksek Lisans Tezi.

EPA (1995); An Introduction to Environmental Accounting As A Business Management Tool: Key Concepts And Terms, Washington, D.C.

ERDEN A.S.(2004), “Stratejik Maliyet Yönetimi”, Türkmen Kitabevi, 1. Baskı, İstanbul.

ERTUĞRUL, İ., Şavlı, A. (2013). ISO 14001 Çevre Yönetim Sistemi ve Bakır Mamulleri Sanayine Uyarlanması. Çankırı Karatekin Üniversitesi İ̈BF Dergisi. Cilt:3. Sayı:2. ss.223-238.

ESMERAY, Murat ve Şükran Güngör Tanç (2009); "Çevresel Maliyetlerin Mamullere Yüklenmesinde Kullanılan Dağıtım Anahtarlarının Seçiminde Analitik Hiyerarşi Yöntemi ve Bir Uygulama," Süleyman Demirel Üniversitesi İktisadi İdari Bilimler Dergisi, Say1 2, s. 241-260.

GERSIL, A. (2006), Stratejik Maliyet Yönetimi Kapsamında Ürün Yasam Seyri Maliyet "Yönteminin Analizi ve Bir İşletme Uygulaması, (Basılmamış Doktora Tezi, Ankara)

GÜNDÜZ, E. (1997), Dünya Klasındaki İşletmelerde Bir Maliyet Yönetim Aracı Olarak Faaliyete Dayalı Maliyet Sistemi ve Bir Uygulama, SPK Yayın No:99, Ankara, s.33.

HANSEN, Don R. ve Maryanne M. Mowen (2000); Cost Management: Accounting and Control, South-Western Collage Publishing, United States of America.

KARABULUT, E. (2004). İşletmelerde yeşil yönetim uygulamalarının işletme başarısına katkısını incelemeye yönelik bir araştırma. İstanbul Üniversitesi İşletme Fakültesi Dergisi, 33(1), 51-68.

KARAFAKIOĞLU M. (2005), “Pazarlama İlkeleri”, Literatür Yayınları,1.Baskı, İstanbul.

KARAKAYA Mevlüt, (2004). Maliyet Muhasebesi, Gazi Kitabevi, Ankara

KARAKAYA, M.(1999). Üretim Yaşam seyrindeki Değişim ve Standart Maliyet Sistemi. MÖDAV Muhasebe Bilim Dünyası Dergisi, Cilt:1, Sayı:1,Mart

KARAKAYA, Mevlüt (2006), Maliyet Muhasebesi (2. Bask1), Ankara: Gazi Kitabevi.

KARCIOĞLU, R.(2000). Stratejik Maliyet Yönetimi, Erzurum: Aktif Yayınevi 
KAYA, Uğur ve İdris Varıcı (2008); “Gelismekte Olan Ülkelerde Çevresel Raporlama: Türkiye Örneği,” Muhasebe Bilim Dünyası Dergisi, Cilt 10, Sayı 4, s. 209-227.

KIRLIOĞLU, Hilmi ve Ahmet Vecdi Can (1998); Çevre Muhasebesi, Değisim Yayınları, Adapazarı.

KLASSEN, R.D. (2000), "Exploring the Linkage Between Investment in Manufacturing and Environmental Technologies", International Journal of Operations and Production Management, 20(2): 128-131.

KORUL, V. (2003). Havaalanı Çevre Yönetim Sistemi, Anadolu Üniversitesi Sosyal Bilimler Dergisi. Cilt:3. Sayı:1. s.99-120.

KÖSE. T. (2000). Stratejik Kar Yönetim Aracı Olarak Hedef Maliyetleme ve Türkiye Şeker Fabrikaları A.Ş. Eskişehir Makine Fabrikasında Bir Uygulama Anadolu Üniversitesi Sosyal Bilimler Enstitüsü (Yayınlanmamış Yüksek Lisans Tezi), Eskişehir

KÜÇÜK, E. (2009). Yeşil Pazarlama Etkinlikleri Açısından Yeni Ürün Geliştirme. İstanbul Ticaret Üniversitesi Sosyal Bilimler Enstitüsü İşletme Anabilim Dalı Yüksek Lisans Tezi.

LUND Robert T. (1978), "Life-cycle costing: A Business and Societal Instrument", A Division of American Management Associations, April.

MEHMET Ersoy, (2002). ”Ömre Dayalı Maliyetleme", Muhasebe Bilim Dünyası Dergisi, Cilt:4, Sayı:2, s.51.

NEMLİ, Esra (2001); “Çevreye Duyarlı Yönetim Anlayışı,” İstanbul Üniversitesi Siyasal Bilgiler Fakültesi Dergisi, No:23-24 (Ekim 2000-Mart 2001), s. 213

NEMLİ, E. (2000), Çevreye Duyarlı Yönetim Anlayışı, İ.Ü. Siyasal Bilgiler Fakültesi Dergisi, 23-24

ÖMER BAYBARS TEK, Pazarlama ilkeleri, 8.Basım, Beta Basım Yayım Dağıtım İstanbul, 1999,

ÖZBİRECIKLII M (2000). Çevre Muhasebesi Kavramı ve Yönetsel Kararlara Katkıları Muhasebe ve Finansman Dergisi 7, 15-21.

ÖZBİRECIKLİ, Mehmet ve Zeynep MELEK (2002); "Çevre Muhasebesi ve Çevresel Maliyetlerin Maliyet Muhasebesi Sistemine Etkileri ve Bir Araştırma," Muhasebe ve Finansman Dergisi, Sayı 14, s. 82-91.

SAKURAI, M.(1996). Integrated Cost Management: A Companywide Prescription for Higher Profits,Portland,Oregon:Productivity Press

SEVILLENGÜL, Orhan (2005); Genel Muhasebe, Gazi Kitabevi, Ankara.

SEVIM, A. (2002). Stratejik Kar Yönetiminde Çağdaş Bir Araç: Ürün Yaşam Seyri Maliyet Sistemi. MÖDAV Muhasebe Bilim Dünyası Dergisi, Cilt:4,Sayı:1,Mart

ŞAKRAK, M.(1997). Maliyet Yönetimi, İstanbul: Yasa Yayınları

TAM, V. W, Tam, C. M, Zeng, S. X, \& Chan, K. K. (2006b). ,Environmental Performance Measurement İndicators in Construction '. Building and Environment, 41(2), 164-173.

TEKİN Mahmut, (2000). Üretim Yönetimi, Cilt:1, Arı Ofset, Konya.

TíTiz, İ. ve Çetin, C. (2000), Karar Almada Geleneksel Maliyet Yönetimi Yaklaşımında Yaşanan Gelişmeler Ve Stratejik Maliyet Yönetimi, Isparta: Süleyman Demirel Üniversitesi. İktisadi ve idari bilimler fakültesi. C.5. S.2.

ULUSAN, Hikmet (2009); "Çevresel Raporlama Rehberleri ve işletme Çevresel Raporlarında Açıklanması Gereken Bilgiler,” Süleyman Demirel Üniversitesi iktisadi idari Bilimler Dergisi, Cilt 14, Sayı 2, s. 181-206.

USTA, R. (2007). Otel işletmeciliğinde çevre yönetim sistemi uygulamaları (Yayınlanmamış Yüksek Lisans Tezi). Selçuk Üniversitesi Sosyal Bilimler Enstitüsü, Konya.

YAVUZ, A. (2010). Sürdürülebilirlik kavramı ve işletmeler açısından sürdürülebilir üretim stratejileri. Mustafa Kemal Üniversitesi Sosyal Bilimler Enstitüsü Dergisi, 7(14), 63-86.

YILMAZ, Rıfat ve ARI Mustafa (2011). Ürün Yaşam Seyri Maliyet Analizi ve Ürün Yaşam Seyri Maliyetleme Yaklaşımları için Durum Değerlendirmesi ve Kavramsal Çözümleme İhtiyacı Muhasebe ve Finansman Dergisi, (49).

YÜKSEL, H. (2003). İşletmelerin Çevreye Duyarlı Üretim Faaliyetlerinin Ampirik Bir Çalışma İle Değerlendirilmesi. Endüstri Mühendisliği Dergisi. Cilt:14. Sayı:2 (Haziran). 